\title{
Boys' Anti-School Culture? Narratives and School Practices (Last draft)
}

\section{Published in: Journal of Anthropology and Education Quarterly}

Jonsson, Rickard (2014). Boys' anti-school culture? Narratives and school practices. Journal of Anthropology and Education Quarterly, 45 (3), 276-29.

\begin{abstract}
'Boys perform worse and worse in school and that is a situation we can no longer accept' [says Swedish Minister for Education Jan Björklund]. He believes that new pedagogical methods, where the pupils mainly have to work on their own, may have contributed to that development. 'That method benefits girls, who usually are more mature compared with boys of the same age, while many guys prefer a coffee break instead of doing studying' [---] Jan Björklund believes more male teachers would help to improve boys' results. 'If school is perceived as a very feminine place, there is a risk that some guys think that 'this is not for me'. That's why it is important to have male role models for teenage boys in school', states Björklund. (Sydsvenska Dagbladet 2008 June 13, author's translation)
\end{abstract}

Young men's academic achievement and boys as the new losers in a so-called feminized school has for a long time been the subject of various public debates. These debates are further fuelled by national and international surveys that indicate a gender difference in academic success, where girls and women appear to be winners throughout the educational system (Björnsson 2005; Francis and Skelton 2005; Kimmel 2010). The brief quotation above and the worrying question 
about pedagogic methods that are no longer suitable for boys also echo similar debates in Australia, the United Kingdom and many other OECD countries over the past decades. As noted by many gender scholars (cf. Epstein et al. 1998; Francis 2006; Smith 2003), the issue of gender and school achievement is often portrayed as an educational crisis, and critical voices have underlined the risk of a moral panic as well as a feminist backlash hidden in these debates (Foster et al. 2001; Nordberg and Saar 2005; Smith 2003). Griffin (2000) stated already a decade ago that such debates on boys and their schooling are usually organized around the theme of a "loss". On the one hand, boys are constructed as victims of the educational crisis and, on the other hand, the tone of the public discussion is, in many instances, tinged with nostalgia for a lost masculinity whose superiority is left unchallenged. Also note the causality between pedagogics and boys' lower grades pointed out by the minister in the citation above, where gender is seen as something crucial for teaching (boys need more male role models) and learning (girls can work independently because of their maturity, while boys would rather have a coffee break). Thus, boys and girls are constructed as two distinct, homogeneous and different categories with varying needs. Gender relations are hardly challenged in this short quotation; on the contrary, male teachers are blessed with something specific by virtue of their gender, which is supposed to favour boys' learning.

Moreover, the "rowdy boy" category is taken for granted in this and other similar contributions on the subject. The category may be used to explain rule-breaking activities and disciplinary problems in classrooms, and it is often treated as an unchallenged fact that needs to be dealt with. I argue in this article that it is precisely this category that needs to be explained. This text will take as its point of departure Butler's call (1999) for reversing the relationship between deeds and identity in order to critically discuss dominant conceptions of boys' 
underachievement in school. We need to ask how boys' resistance to teaching can be understood contextually. Drawing on ethnographic data from two school fieldworks, I shall explore how the rowdy boy category is constructed and made intelligible in three cases of school resistance, in order to critically discuss dominant understandings of boys and schooling.

\section{Boys' resistance and underachievement in school}

A theory that has been widely used in both academia and the popular media to explain boys' resistance and underachievement is the thesis of an anti-school culture, established by Willis (1977) in his pioneering work Learning to Labour and several other important contributions which have followed in his tracks. Willis has been criticized, among other things, for not depicting girls and for romanticizing boys' resistance (McRobbie 1980), but his description of an anti-school culture among young men has not been attacked as much. On the contrary, the idea has won considerable approval, not least in major Swedish public reports on the subject (Björnsson 2005; Skolverket 2006). Even in recent studies, boys' failure in school is often understood as related to either Willis' thesis of an anti-school culture, or to traditional concepts of masculinity (Kimmel 2010:30) or by using Connell's $(1995,2000)$ influential theory of hegemonic masculinity. According to these contributions, to make a serious effort to do well at school is simply not consistent with performing "cool", normative or hegemonic masculinities (Kimmel 2010; Mac an Ghaill 1994).

However, Frosh, Phoenix and Pattman (2003) claim that many of the British schoolboys whom they have interviewed have developed a middle way where they both do popular masculinity and (but more implicitly and quietly) focus on their studies. The authors demonstrate 
how boys in the British study talk about the importance of gaining good grades, but they have to make it look like they have done it without making any effort (cf. Nyström 2012).

Furthermore, I concur with scholars who have stated that there are reasons for drawing attention to other categorizations than gender when investigating students' different learning outcomes (Lahelma 2005; Nordberg and Saar 2005). Nordberg (2008) argues that various international student assessments are taken as an objective point of departure in discussions on boys' achievement in school, whereas class, ethnicity, parents' level of education, area of residence or any other aspect of student diversity, needs and resources risk to be ignored. Griffin (2000) points out that the reason why class is so seldom mentioned in relation to academic achievement is not that it would have become an irrelevant or outdated aspect, but because it no longer needs to be mentioned. Boys are constructed as a homogeneous group within the dominant discourse on their underachievement, but there is an implicit understanding of which boys are actually at risk - often categorized as working-class, diagnosed boys or ethnic Other boys (cf. Francis 2006; Nyström 2012; Reed 1999; Velasquez 2012). Discourses on boys in crisis may therefore actually reproduce a normative masculinity at the same time as it marginalizes other groups of pupils as deviant and as those who need to be brought up and disciplined.

To summarize, much work on the theme of failing boys in school have applied Willis' notion of an "anti-school culture", Connell's $(1995,2000)$ social theory of gender and hegemonic masculinity or other perspectives with the aim to give the big picture of boys' behaviour in school. However, Willis's notion of anti-school culture and Connell's hegemonic masculinity has taken on a life of its own and become taken-for-granted in several texts discussing the issue the last decade. That statement of mine is not primarily a criticism of Willis' or Connell's work but a 
questioning of how contemporary reports on gender and schooling, articles in popular media and political proposals on boys and schooling have come to use the concepts. The socioeconomic conditions of the lads from working class England four decades ago, are sometimes forgotten when the notion of anti-school culture is applied on boys and schooling in contemporary Western societies. When the Swedish Minister for Education, representing the right-wing government, refers to the concept in contemporary debates on failing boys, it is doubtlessly given a new meaning - but what exactly is it referring to? In this article, I argue that it is crucial to analyse school resistance in local contexts, just as Willis and others have done successfully in their research. Following the call of Epstein, Elwood, Hey and Maws (1998) in their now-classic book Failing Boys? we need to ask which boys in which specific contexts challenge classroom norms, and with what performative effects.

\section{Methodology and school context}

The data used in this article is taken from two ethnographic studies in two secondary schools, both of them situated in multi-ethnic suburbs of Stockholm. The schools are referred to as the South (project 1) and the North (project 2) school in the text. Despite a widespread image of Sweden as an equal welfare society, the multiethnic suburbs of Sweden's larger cities have become associated with social and ethnic segregation, unemployment, discrimination, poor Swedish language skills and, not least, underachieving students in underachieving schools (Bunar 2011:142). Since Sweden in the beginning of the 90:ies introduced a free choice model with the right for students to choose school, the low status schools in the low status areas have witnessed a flight of pupils to the inner city, and schools situated in multi-ethnic and socially deprived areas struggle with bad reputation and low status (Kallstenius 2010). The both schools in this article 
can be described as such examples. That is made explicit by students when they in jokes as well as serious answers to my questions describe their own school as low status schools with students who perform lower results then average. Even though many students I am following do reach good grades, the narratives of the low performing suburb schools, and especially the "failing immigrant school boy", flourish among the informants. In addition Swedish media contribute to establish this image by comparing schools achievement, recurrently publishing the average grades of all Stockholm schools and thereby providing a picture of the winners and losers of the educational market, which in turn, even further strengthen the pattern of fleeing students from the low status suburb schools. In parent's choice of schools for their children, perceptions of Swedishness vs. multiculturalism also seem to have a major impact, where the attractive schools of the inner city may flaunt with motivated students with excellent Swedish language skills (Bunar 2011). Due to low income jobs and unemployment in the multi-ethnic suburbs, ethnicity and class is highly interwoven here, and when I talk about students in multi-ethnic schools, many of them could likewise be described in terms of children of a new Swedish working class. However, in this article gender rather than ethnicity and class is the primarily focus since I want to highlight the assumptions made in the Swedish reports and public debates of the rowdy boy category (Björnsson 2005; Kimmel 2010; Skolverket 2006). Nonetheless, the described context of the two multi-ethnic schools is indeed relevant for the cases I present.

Project 1 took place in a secondary school in a suburb south of Stockholm over a period of one year, from 2003 to 2004 . About half of all students at the school have an immigrant decent (both their parents were born outside Sweden) or they had themselves migrated to the country. The school's principal once told me that it is absolutely crucial to "keep the fifty percentage of Swedish students", in order to not risk the school's reputation (To clarify, the vast majority of the 
school's students are Swedes, in the meaning of being born in Sweden and being Swedish citizens, but I guess the principal in this case was referring to racial and ethnic categorisations). I spent three days a week in the school at lessons and breaks during the pupil's whole school days. Methodologically, the project involved: tape-recordings of informal conversations; participant observation annotated in the form of field notes (about 400 printed pages); five group interviews, and twelve individual interviews with students at Year 8 and 9 (age 14 - 16).

Project 2 was conducted in a secondary school north of Stockholm, situated in a multiethnic setting, with a majority of its population being themselves immigrants or having parents who migrated to Sweden. As part of a commissioned research project, with the explicit task to comment on why boys from the municipal's school perform lower results than the nation average, I followed the students two days a week between September 2007 and February 2008, a period during which I observed five of the school's classes at Year 6 - 9 (age 12 - 16). Field notes (about 100 printed pages) were complemented with tape recordings of naturally occurring talk and semi-structured group interviews with eighteen pupils. When I in this article present excerpts of conversations, I am referring to data that is audiotaped and transcribed. When I present students' conversations in text with quotation marks but without using excerpts, I am utilizing data that was documented by my field notes, which were written down as the conversation was taking place.

I followed both male and female students who do well and less well in school in order to obtain a variety of narratives and perspectives on the subject. Since I am interested in the performance of gender and student positions in everyday school life, the participant observations together with tape recordings of naturally occurring talk has been privileged over individual 
interviews in my data collection. However the conducted interviews, which I consider as another example of social interaction and as jointly produced by the researcher and the researched, still offer an opportunity to have the topic of gender and school achievement discussed under circumstances that differs from interaction in classroom and breaks, and thus provides additional perspectives to the subject.

Let me finally comment on the selection of presented data: during my time in the two schools I daily noticed examples of students making fun of school, lessons or teachers. The examples of these stories were plenty; how Nima once threw a chair out of the class room window; how Emre trigged the fire alarm so that he got everybody to leave the school building; how Mengistu told his teacher he was called to a police interrogation, as a fictional story to escape a lesson; how Daniel sent an anonymous letter to his teacher, making a fool of her, et cetera (Author XX). At the same time, my field notes are just as filled with examples of situations where students followed teachers' instructions, where they fulfilled their school tasks or expressed their will of achieving good grades. However, in this article I will present just three cases, selected on the basis that they illustrate school resistance. Needless to say, I do not claim that the examples below are in any way representative of all the interactions that took place in the schools under investigation. Rather, I am choosing three cases of school resistance in order to do an in-depth analysis of what is at stake, and to critically discuss the dominating explanation of boy's anti-school culture. As an alternative to that thesis, the cases will be analysed through a performative and narrative perspective, presented below.

\section{Theoretic framework}


Drawing on Butler's (1999) theory of performativity, the analysis stresses the importance of language use in the construction of gender identities. This implies the recognition of a language's constitutive character. The position of the young male student is understood as being constituted in interaction through talk. This statement should, however, not be interpreted as supposing that individuals are free to "choose their own identity" by using whatever linguistic feature they like. Rather, I regard the rowdy boy as a subject position that emerges through the intersection of both what particular individuals do with linguistic practices and the attitudes about boys and schooling that circulate in public discourse and are transmitted within the school setting itself (cf. Cameron and Kulick 2003). I shall use the concept of style (Coupland 2007) when analysing the linguistic resources which the adolescents in the study use in construction of various identities. The concept includes multiple meanings; as a verb, style can convey the rich semiotic potential inherent in linguistic practices among adolescents. As a noun, however, style also captures the ways in which such practices may over time become perceived by the speakers themselves as fixed and bounded entities, "things" that exist "out there". Finally, as a synonym of "design", style brings with it a sense of "branding", and hence of identity (cf. Coupland 2007). In this way, style highlights the relationship between linguistic practices and the production of different subject positions in discourse.

Furthermore, following Bamberg's call (2006:140) for "small stories" in narrative research, the article shall consider storytelling as an activity that takes place between people, with the narrative emerging at the very point of its telling. This perspective on narratives should be understood in relation to a tradition of studying what we might call more canonical stories, often collected in interviews by a researcher with the ambition to grasp the informants' lengthy and undisturbed stories. On the contrary, a small story perspective takes an interest in stories that are 
jointly constructed in interaction. Following Ochs and Capps I am looking for the "less polished, less coherent narratives that pervade ordinary social encounters and are a hallmark of human condition" (2001: 57). A key issue in the analysis of small stories, Georgeakopoulos (2007:4) states, is to regard narratives as phenomena embedded in local practices and to understand these stories as both emergent and as a result of processes of negotiation and interaction among members engaged in conversation (cf. Stokoe and Edwards 2006). I will pay special attention to one such aspect of narrative action, namely the practice of giving accounts defined by Scott and Lyman as,

[A] linguistic device employed whenever an action is subjected to valuative inquiry. Such devices are a crucial element in the social order since they prevent conflicts from arising by verbally bridging the gap between action and expectation [...] By an account, then, we mean a statement made by a social actor to explain unanticipated or untoward behavior. (Scott and Lyman 1968:46)

Accounts can in this sense be described as forms of justifications which play the role of saving face of the actor giving the account. In a similar vein, Buttny suggests accounts can be viewed as "the use of language to interactionally construct preferred meanings of problematic events" (1993:21). However, Buttny states that accounts have many different functions — as a form of social control; to save face or to remain social relationships. Thus accounts cannot solely be said to have a repairing function, they emerge in social interaction and are given meaning in context. Billig (1996) adds that the purpose of giving an account is far from always to seek consensus, stating "accounts can be controversial, rather than being devices which prevent controversy" (Billig 1996:212). An account can in that sense be described as a sort of disagreement with an 
accusation, so it needs to be performed otherwise others will presume the accused agrees with the blame (Buttny 1993:60). In other words, a blame, accusation or other form of criticism calls the addressed person to offer an account, that is, an explanation "designed to recast the pejorative significance of action and an individual's responsibility for of it" (Buttny 1993: 1, see also Evaldsson 2007).

\section{We have to focus!}

Locally collated statistics on pupils' grades show that the North School has a lower ranking than the municipal average, and boys have somewhat lower grades than girls in all the schools in the area. This is also the reason why I am present in the North school's classrooms; as part of a commissioned research project, I was asked to study and comment on boys' achievement in one of the municipal's schools. With this task in mind, I was sitting in a Swedish class for Year 9 pupils (15 to 16 years old) when the teacher, Inger, instructs the pupils to work in small groups and write a causerie.

Dennis, Nima, Ale and Mark, whom some students in the class describe as "popular" or "those who think they're cool", quickly ask their teacher if they can work in a small group room next to the classroom. While Dennis often is called the Swede among his friends, being blonde with a traditional Swedish sounding name, the others categorize themselves as "immigrants", "blacks" or "blattar" ( a derogatory expression reclaimed by black youths). All of them use a linguistic style called Rinkeby Swedish (named after the multi-ethnic Stockholm suburb Rinkeby). The use of this style confirm the boys position in the class as cool and streetsmart and as affiliated with the multi-ethnic suburb. 
With Inger's permission, the boys enter the group room, and as they close the door the atmosphere changes from quiet classroom chit-chat to loud banter. Dennis looks at me and asks: "Why are you following us?" Before I could answer, Mark suggests: "Well, to get the worst examples!" By posing the question he reminds me for a second about my position in the class. Being a white adult male in my mid-thirties, I was not perceived as one of the boys in school, nor as a teacher, but rather as the name I was given by students; simply "the researcher". I sometimes got the feeling my presence accentuated examples of school resistance, as if the boy's had an idea of what kind of stereotypic examples I was trying to collect. My not fostering attitude, and my habit to take field notes without making any moral judgements whenever a class room rule was overridden, did sometimes evoke laughters and even more rule-breaking activities among the boys I followed. On the other hand, my presence just as often generated accounts from students where they distanced themselves from rule-breaking activities, as a way to resist responsibility for the rule-breaking actions. This time, in the group room, I cannot avoid thinking Mark's description of his group as "the worst examples" is an interesting self-presentation - what exactly is he referring to? Maybe the next few minutes in the group room give us a clue.

On one side of the group room, books and other school supplies are stored on some shelves. There Mark finds some rolls of tape which he starts unwinding so that he can make a ball of tape. Suddenly, Inger opens the door and the lads are caught off guard. They try to hide the ball and pretend to be doing their schoolwork. Nonetheless, Inger notices the ball of tape and tells Mark to throw it in the rubbish bin, whereupon she underlines the importance of concentrating on the classwork. The boys then mumble their explanations as they briefly lean over their textbooks. However, as soon as Inger leaves the room again, Mark says: "Pick up the ball of tape ... she'll kill me if she sees me ... give me the tape too! I hope she won't see me, I don't want no shit!" 
The boys continue chatting while throwing the ball to each other. Now and then, they look out through the room's glass windows to see if the teacher will return. They disobey their teacher's order not to play with the ball, and they risk being found out by the teacher. The very point of this game seems to be exactly this: to collectively break a class rule and dare to take that risk.

This example could serve as an illustration of boys' anti-school subculture where those who are categorized as "cool boys" by their classmates succeed in appearing cool by breaking the class rules. However, whilst playing with the ball of tape, they wonder out loud who should start doing the classwork. This is a lengthy procedure: "I cannot, you can write!" Nima says. "No, I can't be bothered", Ale replies. "We really should be working by now, we have to finish in time!" Nima repeats, commenting on the fact that time was running out in the lesson. Notice how Nima's turn is almost identical to Inger's previous words, even though she is no longer present in the room. After having reminded his comrades of the importance of doing schoolwork, Nima sits down and starts writing the first few lines in his notebook and after a short while Dennis suddenly takes over from Nima as the author of the causerie. He sits in Nima's seat and starts writing where Nima left off. There seems to be a tacit agreement that someone has to assume responsibility to ensure that the work is coming along, while the others keep him company, telling jokes, playing with the ball and being social. Inger once again opens the group room door and asks how they are getting on with the work. "We're discussing the key points today, and putting it in words tomorrow", Nima explains in a way that I perceive as a strategy to confirm that they really are working on the causerie and to conceal the fact that a few minutes earlier they were not doing the work and were clearly breaking the class rules. However, when the teacher leaves the room, the same points are made, but this time it is Nima telling his friends: "Now we've really got to work. We've got to keep up, this is Year nine!" "Well, I can read if you 
write, I'm not important to the group anyway!" Mark states, maybe a strategy to avoid making an effort, but, at the same time, the statement is an excuse; he provides an account (Buttny 1993) for not doing the school task, yet same account includes a norm where you should contribute and be important to the group. All the boys agree to finish the schoolwork and finally Ale summarizes this agreement by asking about the standard of their work: "All right, what grade are we aiming for then, a high or an average one?"

A negotiation of the schoolwork takes place between Dennis, Nima, Ale and Mark, and their positions as pupils emerge in the interaction. It should not be forgotten that breaking school rules is indeed a significant part of what is happening during this lesson. Male bonds are being created in the boys' community by collectively flouting a rule that prohibits playing with the ball of tape and jointly running the risk of being found out. Yet, the same guys also express the importance of being successful in their studies. They use different linguistic resources with various performative effects during the short episode. In the example, Nima uses a linguistic style (Coupland 2007) that is perceived to be the voice of the teacher. Although it doesn't seem to be used as a parody or irony, it does challenges hegemonic discourses of how boys that are categorized in their local school context as the "cool" boys, appear and are expected to speak. By shifting styles, Nima is for a moment embracing the position of the school oriented student.

This situation resembles what Frosh, Phoenix and Pattman (2002: 201) noted about boys' balancing act between performing hegemonic masculinity and being successful students. There is, however, a crucial difference compared with the example above: Drawing on data from individual and group interviews the British study pointed out that boys' school-oriented approach should not be visible to other boys, that young men tried to achieve good grades in school without showing the others their efforts. In this group room, Ale, Mark and Nima are very open 
about the importance of producing good school assignments. The strategy of playing with a ball of tape whilst writing the causerie is probably not the most efficient way of achieving the best grades. But the boys point out, however, that they must make an effort, as demonstrated by their comments: "Come on!" "Now we have to focus!" "This is year nine!" and "What grade are we aiming for?" Obviously, it is possible in the boys' community to express the importance of schoolwork and to ask each other to do the task. In other words, it does not seem to be a refusal to study or a risk of losing face in front of male friends when focusing on schoolwork that explains what is at stake here.

\section{I don't care!}

There are now different types of rule-breaking activities taking place in school, and the above example of the boys who break classroom norms whilst showing a willingness to do well in their studies, is far from the only scenario. Let me make a comparison with another example of school resistance, this time from my ethnographic study at a secondary school in the south of Stockholm. Daniel, a boy aged 14 who I followed closely during my year at the school, is often described by teachers and classmates as a "rowdy boy". When it came to light during my year of fieldwork in

the school that there had been various violations of school rules, I noticed that Daniel was usually singled out as a suspect for questioning; he explained to me that he was summoned to the principal's office, and he had to, in different ways, defend his conduct in school. He describes himself as someone who is "not the teacher's pet", and who dissociates himself from both the teachers and the vast majority of his classmates. Furthermore Daniel position himself as "Swedish", not seldom in contrast to what he perceive as the "disturbing immigrant boys" of the 
school. His statements, jokes and disparaging words on the theme ethnic identity and immigrants is the reason why he is accused by some of his class mates for being racist - a label which he clearly defend himself from. Nonetheless, this allegation further establishes his position among students as somewhat strange, with wrong or immoral beliefs. At school, Daniel sticks to a few friends and, except for these friendships; he describes his school days as a pretty frustrating part of life.

\section{During one of his English classes, Daniel sits beside me at the back of the} classroom. The teacher, Berit, tells her pupils to listen carefully to a tape-recorded story and to be ready to answer questions afterwards about what they have listened to. It is a story about someone at a radio station who makes a prank call and, in jest, tells a lie. Daniel is slouched over his desk and it looks like he is asleep when the teacher turns off the tape recorder and asks him the first question: "Who is the caller?" Daniel replies that he does not know, and Berit is unsatisfied with his answer. "Why don't you know, were you asleep?" Daniel defends himself by saying: "I didn't hear!" Berit rewinds the tape and plays the story once again as Daniel openly goes back to slouching over his desk. When the story finishes for the second time, Berit asks him the same question: "Who is the caller?" "The studio ... ", Daniel begins, but then falls silent. "If I ask you to listen, then you should listen!" "The studio technicians", Daniel replies and Berit confirms that he finally got it right, adding that, in any case, he has to keep up and do what he is supposed to do during her lessons.

The class picks up where it left off. Berit asks her pupils questions on what the story was about, and for a moment Daniel escapes her attention. At the end of the lesson though, Berit once again asks him questions, and once again he cannot give satisfactory answers. Berit now 
switches from English to Swedish, as to emphasize the seriousness of what she says and to ensure that no words will be misunderstood: “Don't you understand that I am disappointed in you, you have done well otherwise!" Daniel replies that he doesn't understand why she would be disappointed in him, saying that he will switch to another teacher's language group anyway, adding; "So I don’t care!”

Daniel's replies and his way of openly slouching over his desk could be taken as an example of the anti-school culture; an illustration of the construction of a normative masculinity by distancing himself from school. However, when I ask other students in the class about it, it does not look like Daniel's comments have gained him popularity, and he does not seem to have performed a hegemonic or cool masculinity; on the contrary, the dominant view among his classmates is he disturbs the lesson, is annoying and is somewhat odd. Instead, I understand Daniel's words as follows: The defiant reply "I don't care" is a linguistic resource that he uses in a classroom dialogue framed by evaluation and discipline. When Berit stresses her questions, Daniel is revealed as someone who is not paying enough attention. This is an accusation that calls for an account. Buttny (1993:21) describes accounts as closely related to the normative organization of adjacency pairs in talk. An adjacency pair is composed by two utterances, expressed by two speakers. Either the second part provides an expected answer to the first parts turn, or she or he gives an account for why the preferred answer does not work. Failure to provide one of these responses counts as violating the adjacency pairs rule (Buttny 1993:42). Daniel clearly provides a dispreferred response, as he answers that he does not know who the caller in the story is. The teacher's questions are not only a test of knowledge; by posing the questions, Berit also blame him for not giving correct answers or for not being watchful at her lesson. The teacher's questions have, in that sense, a disciplinary effect. The dramaturgy of the lesson- 
Daniel is asked questions he initially cannot answer, and the fact that the teacher returns at the end of the lesson with new questions that remain unanswered - consolidate Daniel's position as a pupil who does not do well in school. By claiming that he will switch language groups and telling his teacher that he does not care, he states that he is not dependent on the class, which makes judgements on his behaviour. Thus, the teacher's words cannot have as profound an effect on him. Daniel's account reduces the power of the blame (Buttny 1993). This is in line with Goodwin's finding (1990) that expressions like "I do not care" can be used to demonstrate that the previous speaker's turn will have less impact; it is a strategy to reduce the force of the previous speaker's words; a way to claim that what has just been said is not relevant.

Moreover, I would assert that the rowdy boy category is deeply ingrained in the school's local discourse. Berit's appeals to Daniel, calling upon him to change his behaviour and start listening to the lesson, originate in this position. So does Daniel when he defends himself by saying he does not care. The classroom dialogue evokes this masculine position; it emerges through the dialogue between Daniel and his teacher. According to this interpretation of the situation, Daniel is basically not developing an informal anti-school culture to distance himself from school and to construct hegemonic masculinity. On the contrary, his use of the expression "I don't care" could be understood as a way to escape the accusation that he is failing in school. To be categorized as a failed student, or as a pupil whom the teacher has reason to be disappointed in, is a blame that Daniel seems to defend himself against. At the same time, telling the teacher "I don't care" confirms Daniel's position as the rowdy boy in the classroom.

\section{You shouldn't be a doormat!}


What I have tried to show so far is that any attempts to give a single answer to the question of boys' lower achievement in school fail to do justice to the multi-layered complexity of the issue. This is confirmed when I in group interviews ask students at the North School to reflect on study strategies and gender. One common theme in the boys' as well as the girls' discussions on that topic is simply to express the importance of doing schoolwork properly. It is an answer where the students are performing the role of the well-behaved and responsible pupil and this response should be interpreted in light of the interview context; an adult researcher asking about school and receiving answers where the informants are acting as the serious student. However, my data is full of other examples where the same students distance themselves from the position of the successful student. A recurring response when I ask the students to describe how a good student is expected to act, or what the characteristics of a successful study strategy are, is that one should be attentive and willing to follow the teacher's instructions. This student position seems to include a problem in that there is a lack of agency. On one occasion, Ale and Saman speak ironically about being able to follow instructions, and then, in a more serious tone, they add that students awarded the highest grades "are silent and feel embarrassed".
A - Ale (student)
S - Saman (student)
R - Researcher

Ale: $\quad$ Like it's like this, what do you call it? Girls who feel embarrassed and are quiet all the time

Saman: $\quad$ They get the good grades! 
A: $\quad$ Even if they do badly, even if their results are bad but they're kind

Researcher: What do you mean they feel embarrassed? I think that's interesting

A: $\quad$ Well, they're quiet, they do not talk and they don't dare to speak

R: $\quad$ No, and then you get good grades?

A: $\quad$ Yes that's (.) yes kind of, or like if I've got good grades good results but at the same time I'm a bit disruptive then maybe someone else who's quiet and feels embarrassed and who has worse results than me, they can still get just as good grades as mine or even better! [---]

R: $\quad$ Does that go for both boys and girls or is it

A: $\quad$ For girls because most guys are not so quiet (yes) and then they say that you should be active and participate in the lessons (.) but (1.0) it seems that when you don't participate you get good grades

The above discussion includes a metalinguistic reflection: what Ale portrays as a successful study strategy is at the same time a description of a linguistic style (Coupland 2007) characterized by not speaking during a classroom discussion and by feeling embarrassed, which the boys in their comments index as something feminine. In his first turn, Ale makes this connection between gender and speech style when he mentions "girls who feel embarrassed and are quiet". Here, Ale makes a comment on gender and language as well as on academic performances — two phenomena which, according to his description, are closely connected. 
Lakoff (1975), in her work on gender and language, launched already four decades ago the idea of a specific feminine language that is characterized by a few different features. For example, Lakoff pointed out women's use of hedges and apologies, which might downplay the authority in what is being said, in contrast to what Lakoff described as the characteristics of men's language. Lakoff's contribution has later been described as a deficiency model, in which women's speech was understood in terms of deficiency in relation to a normative masculine language (Bucholtz and Hall 1995). Therefore, many third-wave feminist linguistic scholars have highlighted that what seem to be descriptions of gender differences in language should rather be understood as language ideologies, id est dominant notions of language loaded with specific values and attributed meanings (Cameron 2005:447; Author XX, Author XX). Ale and his friends reproduce an established language ideology where girls' linguistic styles are described by such words as "embarrassed", "quiet" and "don't dare to speak". They do so as an answer to the researcher's question of whether the silent student they are talking about is gendered, which Ale also states in his opening turn. This is an example of the relational aspect of gender construction. Femininity is in the boys talk constructed in relation to masculinity; as something they are not part of, as something with a lower value associated with characteristics such as cowardice and obsequiousness (c.f. Frosh et al 2002). The boys connect this feminine style to being successful in the school system. Being quiet, and being a girl, is according to the boys rewarded with high grades in the school's hidden curriculum (Jackson 1968).

Ale continues the conversation a little bit later, saying that in order to succeed in school, you have to "brown-nose". "You have to bake biscuits and bring music from your country of origin", Dennis adds, as one of the girls in his class once did. "Be nice and do your homework", Saman continues; "Never argue!" Dennis adds, and once the topic is introduced, the 
examples seem to never end: "Don't be late, do not talk during classes because even if you are smart and know the subject, your chances are ruined if you talk too much". "So then they will judge you before they've seen your results", Ale says, and Nima agrees: "Exactly, they judge you if you talk in the classroom".

What performative work is being done here? According to a small story perspective, narratives are constructed jointly in interaction (Bamberg 2006; Georgeakopoulos 2007). This is an analysis which, using Phoenix's words, draws attention to how people "build their narratives and the performative work done by the narratives. This allows insights into the dilemmas and troubled subject positions speakers negotiate as they tell their stories" (2008:64). Through the story about "girls who feel embarrassed", the boys construct themselves as autonomous, independent and unfairly treated. Both the "unfair adult teacher" and the "brownnosing girl" category are used to explain why they themselves are unable to achieve higher grades or why there is no point studying more than they already do. They tell a story where the word embarrassed, along with the strategy to brown-nose, includes aspects of subordination to the teacher's authority but also performs expected pupil identities — in the boys' account, a student passes as a good student by not challenging the teacher's position, and a student with an immigrant descent is expected to perform the stereotypic "immigrant student" who "brings biscuits and music from their homeland".

Their ironic comment shall be interpreted in relation to an ethnic essentialism that is sometimes expressed by schools' staff when non-white students who happens to have parents born outside Sweden, are affirmed as "immigrant students". This is done in a positive tone which nonetheless makes ethnicity to a marker of difference, whereas the white student on the contrary 
is unmarked, and not attributed with culture or ethnicity (see Dyer 1997). In addition, I have shown in previous writings (Author $\mathrm{XX}, \mathrm{XX}$ ) how the young immigrant lad is often associated to trouble, disturbance, and improper language use within same discourse. I have discussed this phenomenon as an interpellation (Althusser 1971) where students who are categorised as "immigrant boys" risk to be addressed by school staff, media, researchers and others as problematic students, in need of special support or, in worst cases, as youths whose attitudes, language and values a priori are perceived as something that needs to be fostered and changed. However, in the excerpt, the boys critically points out an equally common stereotype; that of the well-behaved immigrant girl, doing house work and baking cookies based on a "ethnic recipe."

Furthermore, there is a gender work going on in the telling of the various student strategies. Even though much school ethnographic research shows examples of the active, gender bending school girl, or the cocky workings-class girls who connect "being a nice girl" to a deficit and a lack of toughness and personality (Ambjörnsson 2004; Reay 2001; Thorne 1993), the narrative of the silent and obedient girl remains firm - used by the boy's in the excerpt above in construction of masculinity and student positions. The story is not just one of many to be told but the one that is most encouraged in the conversation, and so a description of who they are, in relation to whom they are not like (girls and teachers) is constructed in interaction. The way Ale, Nima and Saman construct an independent masculinity by distancing themselves from fawning girls thus repeats a dominant discourse that was also expressed earlier in this article by the Minister for Education, when he said that the girls are more adapted to studying and schools' pedagogic methods suit girls better than boys. Here dominating discourses in public debates on a feminized school are drawn upon by some young men in a conversation where they jointly construct their student and gender identities. 
Most importantly, the boys' description is more a criticism of pupils' lack of agency than a refusal to do schoolwork. They do not distance themselves from the official requirement of the curriculum — to participate in classroom discussions — but, instead, from being quiet and subordinated. Berivan and Shirin, two girls from middle class homes, who have very good grades, give a similar description when I ask them about their study strategies. They point out that although they both achieve good grades in school, they do not always intend to be hardworking students, and it would probably not even be wise for them to do so:
S- Shirin (student)
B- Berivan (student)
R - Researcher

Shirin: Well, you can't go nine years in school without getting thrown out of the classroom at some time or other! Without getting told off at some stage and without anything bad written in your absence report, it just isn't possible, you would go crazy, it simply can't be done!

Researcher: What do you mean by that? Why would you go crazy?

S: $\quad$ Hey listen! Imagine you have been in school for nine years and just have listened to what people say and only done what others are telling you to do (1.0) how would you then cope with working life after school? It doesn't work!

R: $\quad$ No, so you also need?

S: $\quad$ Your boss would take the rip! [In original "driva sönder", meaning tease and exploit]

(Berivan laughs) 
R: What else do you need then?

S: $\quad$ You would become a doormat, it doesn't work! You have to

R: $\quad$ So instead you have to?

S: $\quad$ Well different opinions, sometimes you just have to live!

R: $\quad$ But what does that mean? Just to live?

S: $\quad$ You can't simply be a school person, just go home from school, back to school! (yeah) then you would go completely (1.0) insane!

B: $\quad$ Instead go out sometimes, go home, eat and take it easy

Berivan and Shirin are talking about the school's disciplinary tools; students can be removed from the lesson, get told off or have comments written in the reports sent home to their parents. Despite these punishments for an undesirable behaviour, and even though they themselves really are aiming to achieve high grades, Shirin and Berivan claim that there are still reasons for violating the position of being completely loyal to the teaching. "You can't simply be a school person", as Shirin says. Berivan and Shirin seem to denote a different ability, beyond those that are rewarded in the classroom. This ability could be described as acting independently. "Take it easy" and "go out" are used by the girls as positive words that indicate independence in relation to school and studies. Being a "school person" who never gets told off or removed from classes is taking it too far. "The boss would take the rip", as Shirin puts it. Two dichotomies are present in the girls' story, namely between being active and passive and independent and obedient. The cost of being a loyal student is a loss of agency. The passive student was previously made feminine in the boys' conversation, but it is, nonetheless, a position that also Berivan and Shirin clearly 
distance themselves from. Neither of them wants to be the loyal student if it requires subordination and a loss of agency.

\section{Discussion}

Willis' notion of an anti-school culture together with Connell's concept hegemonic masculinity, have been tremendously influential in research on boys and schooling. Let me finally discuss a shortcoming in the use of these concepts, and as an alternative for further research within the field, advocate the need of looking for various linguistic recourses used among students in their everyday school life. Connell's concept of hegemonic masculinity can be defined as the idealized way of being a man. As Connell and Messerschmidt write in a reflection on the notion:

"Hegemonic masculinity [---] embodied the currently most honoured way of being a man, it required all other men to position themselves in relation to it, and it ideologically legitimated the global subordination of women to men" (2005: 832).

Yet, as Hearn and others (Hearn 2004; Hearn et al 2012) has pointed out, the usage of the concept risks to generate substantive studies on men, producing a static typology of masculinities. Furthermore, it is hard to tell who enact the hegemonic masculinity, although the macho man or the protesting rowdy school boy has often been associated to the concept. To take one example; when Frosh et al (2002) identify an oppositional school culture in their rich individual- and group interview data, the hegemonic masculinity is defined by the authors as antithetical to being seen to work hard academically (Frosh et al 2002: 198). However, wouldn't same practices of opposition and school rejection be possible to describe as connoted to working class or marginalized masculinities, not in the top of social hierarchies? And what is hegemonic 
masculinity then? Furthermore, when I as a researcher ask school boys about popularity or coolness in individual interviews, I often receive canonical narratives on anti-school cultures and descriptions of gender binaries, but these same narratives might be contradicted - as well as confirmed - by what is being told in small stories, among same informants, in their everyday school life.

Even though Connell and Messerschmidt (2005) clearly reject all usages of the concept hegemonic masculinity that ends up in describing fixed character types, the ambiguity of hegemonic or cool masculinities in the class room, and the risk of understanding gender as a noun, is sometimes blurring the analysis. I argue that the concept of boys' anti- school culture has a similar weakness if treated as a grand narrative to explain boys' attitudes and behaviour in school. It risks taking a substantive approach on gender; it risks pointing out certain boys as belonging to the rowdy boy category, and it fails to elucidate the complexity of students' negotiations of study strategies and pupil identities. In addition, the notion of boys anti-school culture also unable to account for girls' aloofness from the position of the well-behaved student, as we saw in the example of Berivan and Shirin. The thesis may, at worst, reproduce stereotypes of rowdy boys and silent well-behaved girls. Once again, this is primarily not a criticism of Willis' and Connell's use of the concepts, but of how the theories later on has been used in applied projects as well as media debates on boys lower achievement in school.

If we pay close attention to linguistic recourses, we might avoid the risk doing substantive studies on boys in school. The notion of style with its multiple meanings as a verb, a noun and a as a synonym for design, may help us investigate how students "position themselves stylistically and are stylistically interpreted by others" (Bucholtz 2011:2) as they present themselves within 
specific school contexts, engaged in specific social interactions. Furthermore, I have promoted a small story perspective, based on ethnographic field notes, documented naturally occurring talk and group interviews, in order to grasp the co-constructiveness of narratives and to understand how stories about failing boys in school are results of processes of negotiation among students and school staff, engaged in everyday conversations (Georgeakopoulos 2007). Finally, with help from the concept account, we can analyse situations of resistance, with focus on the interactional work being done in specific class room events. Departing from Buttny's (1993:1) description of accounts as talk designed to recast the pejorative significance of action and an individual's responsibility for of it, and thereby transform other's negative evaluations, I argue that situations of protests in class rooms is not necessarily expressions of cool or hegemonic masculinities. When Daniel told his teacher that he did not hear the tape, nor cared about her criticism, he used the expressions to escape the accusation of being a failing student. For further research on boys' resistance to schooling, I therefore call for an analysis that considers various expressions of resistance as linguistic tools, available to some students, in complex and on-going performances of gender and pupil positions in their everyday school life.

\section{Notes}

Transcription conventions: (.) denotes a short pause of less than one second; (1.0) denotes a longer pause, time in seconds; underlined marks something said with emphasis; ? denotes question intonation; ! denotes exclamation intonation; [---] marks removed part of speech or text.

\section{References cited}


Althusser, Louis

1971 Lenin and Philosophy and Other Essays. New York: Monthly Review Press.

Ambjörnsson, Fanny

2004 I en klass för sig: genus, klass och sexualitet bland gymnasietjejer. Stockholm: ordfront.

Bamberg, Michael

2006 Stories: Big or small? Why do we care? Narrative Inquiry 16(1):139-147.

Billig, Michael

1996 Arguing and Thinking: A Rhetorical Approach to Social Psychology. Cambridge:

Cambridge University Press.

Björnsson, Mats

2005 Kön och skolframgång. Tolkningar och perspektiv. Stockholm: Myndigheten för skolutveckling.

Bucholtz, Mary

2011 White Kids. Language, Race and Styles of Youth Identity. Cambridge: Cambridge University Press.

Bucholtz, Mary, and Hall, Kira

1995 Introduction: Twenty Years After Language and Women's Place. In Gender Articulated:

Language and the Socially Constructed Self. Kira Hall and Mary Bucholtz, eds. Pp 1-24.

New York: Routledge.

Bunar, Nihad

2011 Multicultural Urban Schools in Sweden and Their Communities: Social Predicaments, the Power of Stigma, and Relational Dilemmas. Urban Education 46(2): 141-164. 
Butler, Judith

1999 [1990] Gender Trouble. Feminism and the subversion of identity. New York: Routledge.

Buttny, Richard

1993 Social Accountability in Communication. London: Sage.

Cameron, Deborah

2005 Gender and Language Ideologies. In The Handbook of Language and Gender. Janet

Holmes and Miriam Meyerhoff, eds. Pp 447-467. Malden: Blackwell.

Cameron, Deborah, and Kulick, Don

2003 Language and Sexuality. Cambridge: Cambridge University Press.

Connell, R. W.

1995 Masculinities. St. Leonards: Allen and Unwin.

2000 The Men and the Boys. Cambridge: Polity Press.

Connell, Raewyn and Messerschmidt, James W.

2005 Hegemonic Masculinity: Rethinking the Concept. Gender \& Society 19(6): 829 - 859.

Dyer, Richard

1997 White. London: Routledge.

Coupland, Nikolas

2007 Style: Language Variation and Identity. Cambridge: Cambridge University Press.

Epstein, Debbie, Elwood, Jannette, Hey, Valerie, and Maw, Janet

1998 Failing Boys? Issues in Gender and Achievement. New York: Open University Press.

Evaldsson, Ann-Carita

2007 Accounting for Friendship: Moral Ordering and Category Membership in Preadolescent

Girls’ Relational Talk. Research on Language and Social Interaction 40(4): 377-404. 
Foster, Victoria, Kimmel, Michael, and Skelton, Christine

2001 What About the Boys? An Overview of the Debates. In What about the boys? Issues of

Masculinity in Schools. Wayne Martino and Bop Meyenn, eds. Pp 1-23. Buckingham:

Open University Press.

Francis, Becky

2006 Heroes or Zeroes. The Discursive Positioning of 'Underachieving Boys' in English Neo-

Liberal Education Policy. Journal of Education Policy 21(2):187-200.

Francis, Becky, and Skelton, Christine

2005 Reassessing gender and achievement: Questioning Contemporary Key Debates. London: Routledge.

Frosh, Stephen, Pattman, Rob, and Phoenix, Ann

2002 Young masculinities. London: Palgrave.

Georgakopoulou, Alexandra

2007 Small Stories, Interaction and Identities. Amsterdam: John Benjamins.

Griffin, Christine

2000 Discourses of Crisis and Loss: Analyzing the Boys Underachievement Debate. Journal of Youth Studies 3(2):167-188.

Goodwin, Majorie Harness

1990 He-Said-She-Said. Talk as Social Organization Among Black Children. Indianopolis: Indianopolis University Press.

Hearn, Jeff

2004 From Hegemonic Masculinity to the Hegemony of Men. Feminist Theory 2004 (5): 4972. 
Hearn, Jeff, Nordberg, Marie, Andersson, Kjerstin, Balkmar, Dag, Pringle, Keith, Gottzén, Lucas, Klinth, Roger and Sandberg, Linn

2012 Hegemonic Masculinity and Beyond: 40 years of Research in Sweden. Men and Masculinities 15(1). 31-55.

Jackson, Philip

1968 Life in classrooms. Chicago: University of Chicago Press.

Kallstenius, Jenny

2010 De mångkulturella innerstadsskolorna: om skolval, segregation och utbildningsstrategier

i Stockholm. Ph.D. dissertation, Department of Sociology, Stockholm University.

Kimmel, Michael

2010 Boys and School: A Background Article on the 'Boy Crisis'. SOU 2010:53. Stockholm:

Utbildningsdepartementet.

Lahelma, Elina

2005 School Grades and Other Resources: The 'Failing Boys' Discourse Revisited”. Nordic Journal of Women's Studies 13(2):78-89.

Lakoff, Robin

1975 Language and Woman's Place. New York: Harper Colophon Books.

Mac an Ghaill, Máirtín

1994 The Making of Men. Masculinities, Sexualities and Schooling. Buckingham: Open

University Press.

McRobbie, Angela

1980 Settling Accounts with Subcultures: A Feminist Critique”. Screen Education 34: 37-49

Nyström, Ann Sofie 
2012 Att synas och lära utan att synas lära: En studie om underprestation och privilegierade unga mäns identitetsförhandlingar i gymnasieskolan. Ph.D. dissertation, Department of Soiology, Uppsala University.

Nordberg, Marie

2008. 'If We Only Could Enlighten and Modernise Them...' Masculinity, Heterosexuality, Class, Metronormativity, Modernity and Other Intersections in the Swedish Debate on Boys and Achievement". Article presented at the First ISA Forum of Sociology, Barcelona, September 5 .

Nordberg, Marie, and Saar, Thomas

2005 Moralisk panik ersätter kulturanalys. Krut 4:44-63.

Ochs, Ellinor, and Capps, Lisa

2001 Living Narrative. Creating Lives in Everyday Storytelling. Cambridge \& London:

Harvard University Press.

Phoenix, Ann

2008 Analysing Narrative Contexts. In Doing Narrative Research. Molly Andrews, Corinne

Squire and Maria Tambouko, eds. Pp. 64-77. London: Sage.

Reay, Diane

2001 'Spice girls', 'nice girls', 'girlies', and 'tomboys': gender discourse, girls' cultures and

femininities in the primary classroom'. Gender and Education 13 (2):53-166.

Reed, Lynne R.

1999 Discourses of Crisis and Loss: Analysing the 'Boys Underachievement' Debate”. Gender and Education 11(1): 93-110.

Scott, Marvin B., and Stanford M. Lyman 
1968 Accounts. American Sociological Review, 33 (1):46-62.

Skolverket

2006 Könsskillnader i måluppfyllelse och utbildningsval. Stockholm: Skolverket.

Smith, Emma

2003 Failing Boys and Moral Panics: Perspectives on the Underachievement Debate. British Journal of Education Studies 51(3):282-295.

Stokoe, Elizabeth, and Edwards, Derek

2006 Story Formulations in Talk-in-Interaction”. Narrative Inquiry 16 (1):56-65.

Sydsvenska Dagbladet

2008 Pojkarna ska komma i fatt i skolan. 110 miljoner ska bryta antipluggkulturen. June 13.

Thorne, Barrie

1993 Gender Play: Girls and boys in School. Buckingham: Open University Press.

Velasquez, Adriana

2012 AD/HD i skolans praktik. En studie om normativitet och motstånd i en särskild undervisningsgrupp. Ph.D. dissertation, Department of Education, Uppsala University.

Willis, Paul

1977 Learning to Labour. How Working Class Kids Get Working Class Jobs. New York: Colombia University Press. 